\title{
ПРОБЛЕМИ ВПРОВАДЖЕННЯ РЕЗУЛЬТАТІВ ПРИКЛАДНИХ ПСИХОЛОГІЧНИХ ДОСЛІДЖЕНЬ В ОСВІТНЮ ПРАКТИКУ
}

Наукова доповідь на загальних зборах НАПН України 17 грудня 2019 р. https://doi.org/10.37472/2707-305X-2019-1-1-1-4

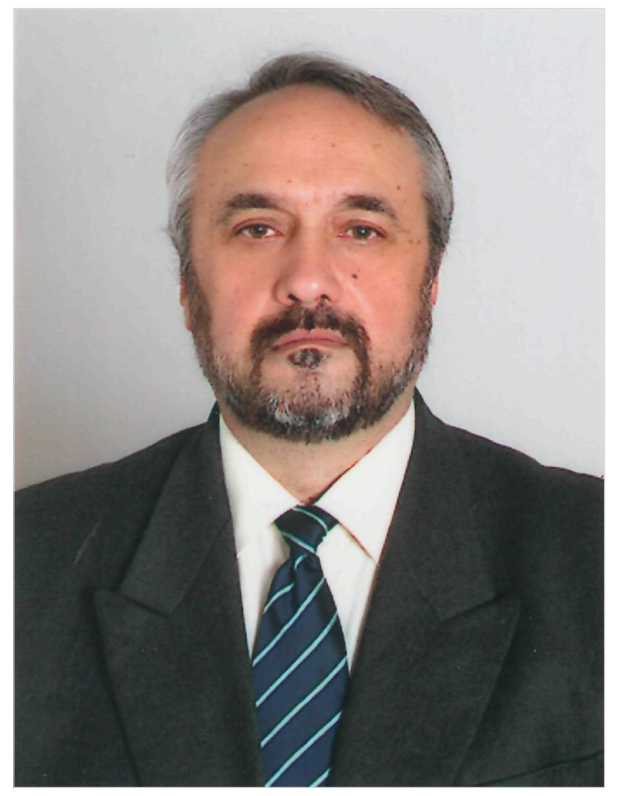

ПАНОК Віталій Григорович доктор психологічних наук, профресор, член-кореспондент НАПН України, директор Українського науковометодичного чентру практичної психології і сочіальної роботи, Національна академія педагогічних наук України, м. Київ, Україна

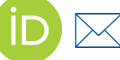

Анотація. Визначено актуальні проблеми впровадження результатів прикладних психологічних досліджень в освітянську практи ку, висвітлюється досвід Українського науково-методичного чент ру практичної психології і соціальної роботи з упровадження інновацій у діяльність психологічної служби системи освіти та окреслено шляхи підвищення ефективності цього процесу.

Запропоновано, зокрема: розробити окремі критерії оцінки результатів прикладних і фундаментальних досліджень; посилити інтеграцію установ НАПН України з МОН України, обласними департаментами освіти і науки, інститутами післядипломної педагогічної освіти та закладами освіти шляхом створення творчих груп, що здійснюють розроблення, експериментальну апробацію $і$ впровадження інновацій; вдосконалити методологію прикладних досліджень у психології, доповнивши ії прочедурами визначення ефективності упровадження. Запропоновані новації потребують оновлення або перегляду існуючих нормативів і прочедур, розроблення або вдосконалення критеріїв оцінки діяльності наукових установ, що здійснюють прикладні дослідження.

Ключові слова: психологія; прикладні дослідження; впровадження; інновації в психології; психологічна практика; система освіти; ефективність упровадження інновацій; удосконалення системи впровадження.

Шановний Василю Григоровичу, шановні члени академії, шановні присутні!

Повністю погоджуючись із висновками і пропозиціями, що прозвучали у доповіді академіка С.Д. Максименка, хотів би звернути вашу увагу на проблеми впровадження прикладних психологічних досліджень у соціальну і освітянську практику.

У першу чергу зауважу, що одним із головних здобутків вітчизняної психологічної науки, нашого Відділення і НАПН України в цілому за усі роки існування незалежної України $€$ створення і розвиток психологічної служби системи освіти та психологічних служб цілої низки відомств, представники яких присутні у цьому залі.

В якості ідеологів створення психологічної служби необхідно назвати академіків В.Г. Кременя, В.І. Лугового, С.Д. Максименка, О.В. Киричука, В.О. Моляка, В.М. Синьова, Т.С. Яценко та інших наших науковців.

Так склалося, що колектив, який я маю честь очолювати Український науково-методичний центр практичної психології і соціальної роботи, здійснював безпосереднє керівництво 
(як методичне, так і організаційне) з перших днів створення психологічної служби, протягом 28 років і дотепер. Створення нашого Центру мало на меті забезпечити ефективне і якомога ширше впровадження досягнень психологопедагогічної науки у практику роботи шкільних психологів і соціальних педагогів. При цьому для забезпечення ефективної роботи практикуючих спеціалістів необхідно було знайти можливості швидкого і якісного впровадження результатів наших досліджень.

Для більш повного розуміння проблеми хотів би перелічити тільки деякі завдання, що висуває педагогічна практика перед працівником психологічної служби освітнього закладу: адаптація дитини до умов навчального закладу на кожному з рівнів освіти; визначення рівнів готовності дітей до навчання; визначення причин академічної неуспішності; профілактика конфліктів у закладі освіти; психологічний супровід професійної діяльності вчителя; психологічна просвіта серед батьків, учнів і вчителів; робота в умовах інклюзивного навчання, допомога дітям з особливими освітніми потребами та їх батькам; профілактика наркоманії, алкоголізму та інших шкідливих звичок; профілактика суїцидальної поведінки; робота 3 обдарованими учнями; професійна орієнтація і консультування; здійснення корекційнорозвиткової роботи; захист прав дитини; профілактика булінгу та інших форм насильства тощо. Це - далеко не повний перелік проблем, з якими звертаються учасники освітнього процесу до наших фахівців.

Тепер про обсяги роботи. Психологічна служба сьогодні - це 23 тис. працівників. У попередньому навчальному році було охоплено індивідуальною профілактичною роботою 549994 здобувача освіти, 108309 педагогічних працівників та 202219 батьків; груповою профілактичною 2625731 здобувач освіти, 426206 педагогічних працівників та 609371 батьків.

Висновок: психологічна служба сьогодні - це соціальне явище, яке помітно впливає на освітній процес, вона не виконує навчальну функцію, вона не виконує виховну функцію, вона здійснює функцію соціалізації підростаючої особистості в умовах закладу освіти.

Для задоволення таких різнобічних потреб практики нам довелося шукати шляхи і засоби впровадження результатів прикладних досліджень.
Аналіз практики впровадження результатів прикладних досліджень у психології показує, що склалась парадоксальна ситуація: система освіти, іiі практичні працівники засвідчують потребу у результатах наших досліджень. 3 іншого боку, відсутні належні умови для задоволення потреб практики в інноваційних психолого-педагогічних методиках і технологіях.

у нашому розумінні впровадження - це не 300 примірників методичних рекомендацій, що розіслані по бібліотеках, а, в першу чергу, застосування інновацій у практичній роботі освітян десятків або сотень шкіл.

Питання: чи можна вважати публікації в Scopus, Web of Science показником упровадження для прикладних досліджень у психології? На наше переконання, це у більшій мірі стосується результатів фундаментальних досліджень. Для прикладних набагато важливішими є публікації у методичних журналах: «Директор школи», «Практичний психолог. Дитячий садок», «Рідна школа», «Початкова школа» та ін., які зараз у річних звітах чомусь підпадають під категорію «зв'язки з громадськістю». Натомість ми вважаємо, що саме перелічені і подібні до них методичні видання мають бути основними в оцінці упровадження інновацій прикладних досліджень у психології.

Найбільш ефективними напрямами впровадження, на наш погляд, $є$ :

- завантаження з сайту Електронної бібліотеки НАПН України, рейтинг авторів за кількістю завантажень (8 співробітників входять до перших 30, двоє - у першу десятку), окремі методичні публікації співробітників налічують по 8-12 тис. завантажень (табл. 1-2).

Таблиця 1

Рейтинг авторів, співробітників Українського науковометодичного центру практичної психології і соціальної роботи за кількістю завантажень в Електронній бібліотеці НАПН України (серед перших 50)

\begin{tabular}{|c|l|c|}
\hline 6. & Обухівська А.Г. & 60,249 \\
\hline 7. & Ткачук І.І. & 54,204 \\
\hline 12. & Ілляшенко Т.Д. & 46,883 \\
\hline 13. & Панок В.Г. & 46,592 \\
\hline 22. & Якимчук Г.В. & 42,198 \\
\hline 25. & Жук Т.В. & 39,528 \\
\hline 28. & Острова В.Д. & 39,136 \\
\hline 31. & Луценко Ю.А. & 36,095 \\
\hline
\end{tabular}


(станом на 25 листопада 2019 р.)

Таблиця 2

Рейтинг ресурсів, авторами яких є співробітники Українського науково-методичного центру практичної психології і соціальної роботи, за кількістю завантажень в Електронній бібліотеці НАПН України

\begin{tabular}{|c|l|c|}
\hline 6. & $\begin{array}{l}\text { Методичні рекомендації «Психологічний } \\
\text { супровід інклюзивної освіти» (2017 р.) }\end{array}$ & 19,854 \\
\hline 16. & $\begin{array}{l}\text { Практичний посібник «Сучасні технології } \\
\text { збереження здоров'я учнів: кращий дос- } \\
\text { від» (2016 р.) }\end{array}$ & 12,348 \\
\hline 24. & $\begin{array}{l}\text { Підручник для закладів вищої освіти } \\
\text { «Психологічна служба» (2016 р.) }\end{array}$ & 10,607 \\
\hline 37. & $\begin{array}{l}\text { Методичні рекомендації щодо впрова- } \\
\text { дження циклограм діяльності працівників } \\
\text { психологічної служби (2017 р.) }\end{array}$ & 8,940 \\
\hline 47. & $\begin{array}{l}\text { Практичний посібник «3 досвіду прове- } \\
\text { дення корекційної роботи практичного } \\
\text { психолога і соціального педагога з дітьми } \\
\text { 3 девіантною та деліквентною поведін- } \\
\text { кою» (2015 р.) }\end{array}$ & 8,112 \\
\hline
\end{tabular}

(станом на 25 листопада 2019 р.)

- Публікації у соціальних мережах. На три сторінки Центру у соціальній мережі Facebook (станом на 26 листопада 2019 р.) загальна кількість підписників - 7505.

За період з 1 січня по 15 жовтня 2019 р. розміщено 96 публікацій, з яких найбільш популярною була публікація про результати роботи наукових працівників Центру у 2018 р. з посиланнями на планові видання. Охоплення цією публікацією 59384 користувачів, репостів - 1318.

Відповідаючи на запити освітян, Центр здійснює розроблення методик роботи з проблеми надання соціально-педагогічної допомоги дітям і сім'ям, що опинились у складних життєвих обставинах внаслідок АТО/ООС. Наукові працівники взяли участь у 9 міжнародних проєктах з названої проблематики. За неповними даними, проведено навчання більше 10100 працівників психологічної служби і педагогічних працівників в основному з районів, наближених до лінії розмежування, що знаходяться у п'яти кілометровій зоні і навіть 3 непідконтрольних територій. Проведено тренінги і консультації для більше 22300 учнів і їх батьків.
Одним із позитивних прикладів упровадження $\epsilon$ реалізація інформаційно-освітньої протиалкогольної програми «Сімейна розмова» для учнів 7-8 класів (табл. 3). За 5 років реалізації Програми у ній взяло участь 99018 учнів.

Наведені дані - не самозвіт, а демонстрація того, що у Центрі за роки його існування накопичено певний досвід і методологію впровадження психологічних інновацій в освітню практику.

Зараз нам необхідно вжити відповідних заходів, щоби підвищити участь працівників психологічної служби в освітніх реформах, зокрема - реалізації концепції Нової української школи, адже вона у першу чергу потребує психологічного супроводу.

Сьогодні склалася така ситуація - якщо розроблення методики більш-менш фінансується державою, то її впровадження у практику не фінансується взагалі! Результат: витрачено державні ресурси, створено науковий продукт, часто не гіршої якості, ніж у зарубіжних колег, але його впровадження у практику не фінансується і часто фактично не здійснюється.

Головне питання для Центру зараз - це підвищення ефективності впровадження результатів прикладних досліджень. Вирішення цієї проблеми ми вбачаємо у реалізації кількох кроків:

Шляхи підвищення ефективності впровадження:

1. Успішна реалізація результатів прикладних досліджень в освітній практиці стає можливою, за великим рахунком, тільки на шляху посилення співпраці з МОН України та підвідомчими йому інституціями.

3 метою підвищення ефективності впровадження результатів прикладних психологопедагогічних досліджень в освітянську практику НАПН України спільно з МОН України та підвідомчими організаціями має розглянути можливість створення міжвідомчих творчих груп за найважливішими напрямами реформування освіти на основі Програми спільної діяльності МОН України і НАПН України на 2020-2022 рр.

Умовами успішної роботи таких творчих груп, на наш погляд, $€$ : спільна методологія

Таблиця 3

Показники впровадження програми «Сімейна розмова»

\begin{tabular}{|c|c|c|c|c|c|}
\hline Навчальний рік & $2010-2011$ & $2014-2015$ & $2016-2017$ & $2017-2018$ & $2018-2019$ \\
\hline Кількість учнів 7-8 класів & 11430 & 34818 & 16305 & 17509 & 18956 \\
\hline Кількість областей & 18 & 11 & 13 & 11 & 12 \\
\hline
\end{tabular}


дослідження - формулювання спільної для усіх учасників проблеми дослідження, мети, завдань, кінцевого результату та спільних етапів дослідної роботи зі збереженням при цьому тематики досліджень окремих учасників; регулярне зібрання учасників з метою координації зусиль науковців, методистів і освітніх менеджерів - координаційні наради; проведення спільних масових заходів науково-практичних конференцій, семінарів, круглих столів; планування і моніторинг процесу впровадження одержаних результатів; забезпечення методичного супроводу інновацій через заклади післядипломної педагогічної освіти шляхом навчання викладачів (тренінги для тренерів і супервізорів) та через курси підвищення кваліфікації педагогічних працівників.

Головним результатом такої системи роботи буде особиста зацікавленість усіх учасників процесу від науковців - до шкільних вчителів. Безперечно, така система роботи вимагає:

а) внесення змін в існуючі процедури роботи як НАПН України, так і Міністерства освіти і науки України, Інституту модернізації змісту освіти, закладів післядипломної педагогічної освіти і місцевих органів управління освітою;

б) уточнення критеріїв оцінювання ефективності роботи як науковців, так і методистів, викладачів і власне практичних працівників освіти.

2. У сучасних умовах конкуренції наукових і методичних продуктів на ринку підвищення кваліфікації важливим є якість методики чи технології, що пропонується до застосування у практиці. Головне у цьому напрямі - суттєво вдосконалити методологію прикладних досліджень у психології і педагогіці. Методологічна підготовка науковціврозробників психологічних інновацій має відповідати світовому рівню. Настав час змінити ідеологічну методологію методологією науковою.

3. Наступний важливий елемент новітньої технології упровадження - авторський нагляд (супровід) інновації. Ми вважаємо: запровадження процедур авторського нагляду $є$ принципово важливим для забезпечення високого рівня ефективності впровадження результатів прикладних досліджень.
4. Необхідно підійти по-новому до визначення і обґрунтування актуальності прикладного дослідження, власне - до формулювання його теми, мети і завдань, організації експерименту та інтерпретації його результатів.

5. Необхідне застосування методик і методів визначення ефективності психолого-педагогічної інновації. При цьому ця ефективність має бути доведена експериментально і обґрунтована статистично, як це здійснюється у відповідності до проектно-технологічного підходу, що розробляється у нашому Центрі останніми роками.

6. Врегулювати організаційно-фінансові питання провадження, зокрема:

- домогтися виконання п. 2 ст.36 Закону України «Про наукову і науково-технічну діяльність» про оплату праці науковців;

- врегулювати питання надання платних послуг з проведення навчальних семінарів і тренінгів, розповсюдження наукової продукції, відряджень науковців, у тому числі і закордонних;

- забезпечити виплату роялті за використання авторських прав у публікаціях і навчанні чи підвищенні кваліфікації.

7. Врегулювати взаємодію відомчих психологічних служб (Міністерства освіти і науки України, Міністерства оборони України, Державної служби України з надзвичайних ситуацій, Національної гвардії України, Міністерства внутршініх справ України та ін.) на основі Міжвідомчої координаційної ради державних психологічних служб при НАПН України.

Аналізуючи сучасні проблеми впровадження результатів прикладних досліджень у психології, можна зробити висновок, що у найближчі роки кризові явища, несприятливі умови і негативні фактори будуть посилюватись. Тому важливо зараз розробляти і застосовувати процедури кризового менеджменту як на рівні окремих наукових установ, так і на рівні НАПН України в цілому.

Дякую за увагу!

\section{СПИСОК ВИКОРИСТАНИХ ДЖЕРЕЛ}

Панок, В.Г. (2019). Проблеми впровадження результатів прикладних психологічних досліджень в освітню практику. Педагогіка і психологія. Вісник НАПН України, (4), 16-24.

\section{PROBLEMS OF IMPLEMENTING THE APPLIED PSYCHOLOGICAL RESEARCHES' RESULTS IN EDUCATIONAL PRACTICE \\ Scientific report at the General Meeting of the National Academy of Educational Sciences of Ukraine, December 17, 2019}




\section{Vitalii Panok}

DSc in Psychology, Professor, Corresponding Member of NAES of Ukraine, Director, Ukrainian Scientific and Methodological Center of Applied Psychology and Social Work, National Academy of Educational Sciences of Ukraine, Kyiv, Ukraine

Abstract. The actual problems of implementing the applied psychological researches' results in educational practice are enlightened in the report. The experience of the Ukrainian Scientific and Methodological Center of Applied Psychology and Social Work on introducing innovations in the education system psychological service activity is highlighted, the ways of increasing the effectiveness of this process are outlined.

It is proposed, in particular: to develop separate criteria for evaluating the results of applied and fundamental researches; to strengthen the integration of the National Academy of Education Sciences of Ukraine with the Ministry of Education and Science of Ukraine, regional departments of education and science, institutes of in-service teacher training and education institutions by creating work groups that carry out the development, experimental approbation and implementation of innovations; to improve the methodology of applied researches in psychology by adding the procedures for determining the effectiveness of implementation. The proposed innovations require updating or revision of the existing regulations and procedures, development or improvement of the criteria for evaluating the performance of research institutions, which carry out applied researches.

Keywords: psychology; applied research; implementation; innovations in psychology; psychological practice; education system; efficiency of innovations implementation; implementation system improvement.

Дата публікації: 23 грудня 2019 р. 